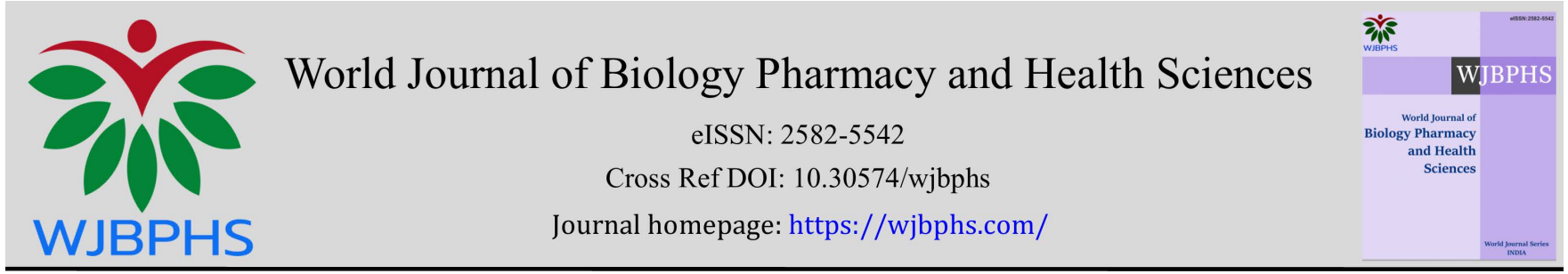

(RESEARCH ARTiCLE)

\title{
Knowledge, attitudes and practices among the population, towards COVID-19 in the Lubumbashi city (DR Congo): An online cross-sectional survey
}

Manya Mboni Henry 1, ${ }^{*}$, Mutombo Shakalenga Cedrick ${ }^{1}$, Bashige Chiribagula Valentin ${ }^{1}$, Nzuzi Mavungu Gaël ${ }^{2}$, Kabamba Tshikongo Arsène ${ }^{3}$, Mutombo Mulangu Augustin ${ }^{4}$, Kibwe Mwenya Cynthia ${ }^{1}$, Moke Mwindu Osé ${ }^{1}$, Nkwanga Jean-Claude ${ }^{1}$, Nsumbu Nzuki Trésor ${ }^{1}$, Bakari Amuri Salvius ${ }^{1}$, Kahumba Byanga Joh ${ }^{1}$ and Lumbu Simbi Jean-Baptiste ${ }^{5}$

${ }^{1}$ Department of Pharmacology, Faculty of Pharmaceutical Sciences, University of Lubumbashi, B.P. 1825 Lubumbashi, DR Congo.

${ }^{2}$ Department of Pre-Clinics, Faculty of Veterinary Medicine, University of Lubumbashi, B.P. 1825, Lubumbashi, DR Congo.

${ }^{3}$ Department of Clinical biology, Faculty of Pharmaceutical Sciences, University of Lubumbashi, B.P. 1825 Lubumbashi,

DR Congo.

${ }^{4}$ Department of Pediatrics, Faculty of Medicine, University of Lubumbashi, B.P. 1825, Lubumbashi, DR Congo.

${ }_{5}^{5}$ Department of Chemistry, Faculty of Sciences, University of Lubumbashi, B.P. 1825, Lubumbashi, DR Congo.

World Journal of Biology Pharmacy and Health Sciences, 2021, 05(03), 001-018

Publication history: Received on 20 February 2021; revised on 26 February 2021; accepted on 01 March 2021

Article DOI: https://doi.org/10.30574/wjbphs.2021.5.3.0016

\begin{abstract}
A survey was conducted online from December 30, 2020 to January 21, 2021, among the population of Lubumbashi city, to assess Knowledge, Attitudes and Practices (KAP) towards COVID-19. The resource persons were self-selected at random, to have freely accepted to answer the online questionnaire. A total of 487 people (50.7\% of women), with an average age of $28.3 \pm 7.7$ years, were interviewed. Overall, $98.2 \%$ said they were aware of COVID-19. This knowledge comes from several sources dominated by television (42.7\%). Several respondents (71.9\%) admitted to being afraid of human-to-human transmission of COVID-19; while 72.1\% hope that this disease will stop one day. Protective practices against COVID-19 contamination are dominated by wearing a surgical mask, social distancing and hand washing (66.9\%). Self-medication either with medicinal plants or with conventional drugs are the most recommended practices by the questioned people, in case of symptoms related to COVID-19 (70.6\%). Most medicinal plants [predominated by Eucalyptus globulus Labill. (45.9\%, $\mathrm{n}=344)$ ] and conventional drugs [predominantly aspirin $(41.5 \% ; \mathrm{n}=41)]$, cited in this case, are reported in various studies as being used in the management of patients with COVID-19. In general, the KAPs observed vary considerably according to the gender and study level of the questioned people. The level of knowledge about COVID-19 among the population of Lubumbashi seems satisfactory and its management acceptable. Practices to control the COVID-19 symptom are predominated by the use of both conventional and non-conventional medicine. However, sensitization of the population of Lubumbashi for a better knowledge and adequate management of this virus is desirable.
\end{abstract}

Keywords: COVID-19; Knowledge; Practices; Self-medication; Lubumbashi; DR Congo

\section{Introduction}

COVID-19 disease is rampant around the world today, killing more than 2424060 people across 223 countries [1]. This disease, first declared on December 8, 2019 in China in Wuhan, has spread very quickly across several countries, creating a global health emergency; as it was declared in March 2020 by the WHO as a pandemic [1-3]. In DR Congo, the

\footnotetext{
${ }^{*}$ Corresponding author: Manya Mboni Henry

Laboratory of Pharmacognosy, Department of Pharmacology, Faculty of Pharmaceutical Sciences, University of Lubumbashi, B.P. 1825 Lubumbashi, DR Congo.
}

Copyright (C) 2021 Author(s) retain the copyright of this article. This article is published under the terms of the Creative Commons Attribution Liscense 4.0. 
first case of COVID-19 was declared in Kinshasa on March 10, 2020 [4]. On the date we submitted this article, DR Congo has 24794 confirmed cases including 695 deaths [5]. In the Haut-Katanga province, the first case of COVID-19 was declared in Lubumbashi on April 24, 2020 [6], and on February 17, 2021, said province has totaled 1160 confirmed cases and 12 deaths [5].

To limit the spread of the COVID-19 pandemic across the world, several measures, including social distancing, the wearing of masks, hand washing and the use of disinfectants, have been put in place [7]. These measures decreed by the World Health Organization (WHO), were relayed in DR Congo by the ministry of health and disseminated through websites, newspapers, radio and television broadcasts, as well as in the form of posters placed on public places [4]. This information aims in particular to provide the population with various knowledge related to the COVID-19 pandemic and the recommended measures, in order to enable them to protect themselves against this pandemic [8]. On the other hand, several information continued to be published, in particular on the treatment using different types of drugs [9], medicinal plants $[3,10,11]$, and as well as vaccines, against the COVID-19 pandemic [12].

It is recognized that the behavior and practices adopted by the population are strongly influenced by their levels of knowledge and the types of information available to them [13, 14]. This shows the importance of assessing the knowledge, attitudes and practices adopted by the population in the face of the COVID-19 pandemic, in view of the volume and diversity of information shared $[8,15]$. To date, several works have already been carried out in this direction, in several countries around the world [2, 8, 13-17]. In DR Congo, currently four studies have already been carried out on the KAPs especially among (i) workers in private pharmacies, in the commune of Kintambo in Kinshasa [4]; (ii) among students of the Higher Institute of Medical Techniques (from French, Institut Supérieure des Techniques Médicales, abbreviated ISTM) in Lubumbashi [6]; (iii) among the general population in Gbado-Lite city [18]; and (iv) general population in Mbujimayi city [19]. No such study has been carried out among the general population in HautKatanga province, and even less in the city of Lubumbashi. In addition, the practices studied among ISTM students in Lubumbashi were not presented explicitly. It is within this framework that this study set the main objective of assessing the knowledge, attitudes and practices of the population of Lubumbashi in the face of the COVID-19 pandemic.

\section{Material and methods}

\subsection{Study area and design}

This is a cross-sectional descriptive study carried out in the Lubumbashi city (Figure 1), Haut-Katanga province, in the south-east of DR Congo [20]. Lubumbashi city is located between $11^{\circ} 27^{\prime}$ and $11^{\circ} 47^{\prime}$ south latitude, and between $27^{\circ} 20^{\prime}$ and $27^{\circ} 40^{\prime}$ east longitude [21]. With an area of $747 \mathrm{~km}^{2}$, this city is subdivided into 44 neighborhoods, distributed into 7 communes [22]. The Lubumbashi city is home to a diversity of people, coming from all the provinces of DR Congo; this population speaks mainly Swahili and French [23]. There has not been a census everywhere in the country since 1984, the available data on the population come from projections made with the population growth rate [24]. In 2021, the inhabitants number of the Lubumbashi city is estimated at 2584000 , i.e. a density of 3,459 inhabitants $/ \mathrm{km}^{2}$ [25]. The health profile of this city is that of tropical regions, characterized by the predominance of infectious and parasitic diseases [26,27]. The provision of health care is based on conventional medicine and traditional medicine [28].

\subsection{Study population and sample size calculation}

Given the lack of data on KAPs toward current COVID-19 pandemic in several segments of the population of the Lubumbashi city, we have targeted the general population. The sample size was calculated on the basis of the estimated population size of the Lubumbashi city (2 584000$)$ [25]. Equations 1 [29, 30] and $2[30,31]$ were used to calculate and adjust the sample size. The number of questionnaires to be shared was calculated considering a response rate of approximately $30 \%$, for an online survey [32].

Equation $1: \mathrm{n}=\left(\left(\mathrm{Z}_{-} \alpha\right)^{\wedge} 2 \cdot \mathrm{p} \cdot(1-\mathrm{p})\right) / \mathrm{i}^{\wedge} 2=\left((1.96)^{\wedge}(2) \cdot 0.5 \cdot(1-0.5)\right) /(0.05)^{\wedge} 2=384.16$

Equation $2: \mathrm{n}(\operatorname{adj})=\mathrm{n} /((\mathrm{n}-1) / \mathrm{N}+1)=384.16 /((384.16-1) / 2584000+1)=384$.

With $\mathrm{n}=$ sample size for a population with indefinite size; $\mathrm{Z} \alpha=\mathrm{Z}$ value corresponding to the error margin of $0.05 ; \mathrm{p}=$ proportion of the population experiencing COVID-19 pandemic (generally set at 0.5 for a population whose true value is unknown) [30]; $\mathrm{i}=$ the used error margin. In the equation $2, \mathrm{n}_{\text {adj }}=$ adjusted sample size and $\mathrm{N}=$ the study population size. The minimum sample size being calculated at 384 respondents, the number of questionnaires to be shared was calculated at 1280. In practice, the questionnaire was sent to around 2000 people, of whom 503 took part in the survey in the city of Lubumbashi. 


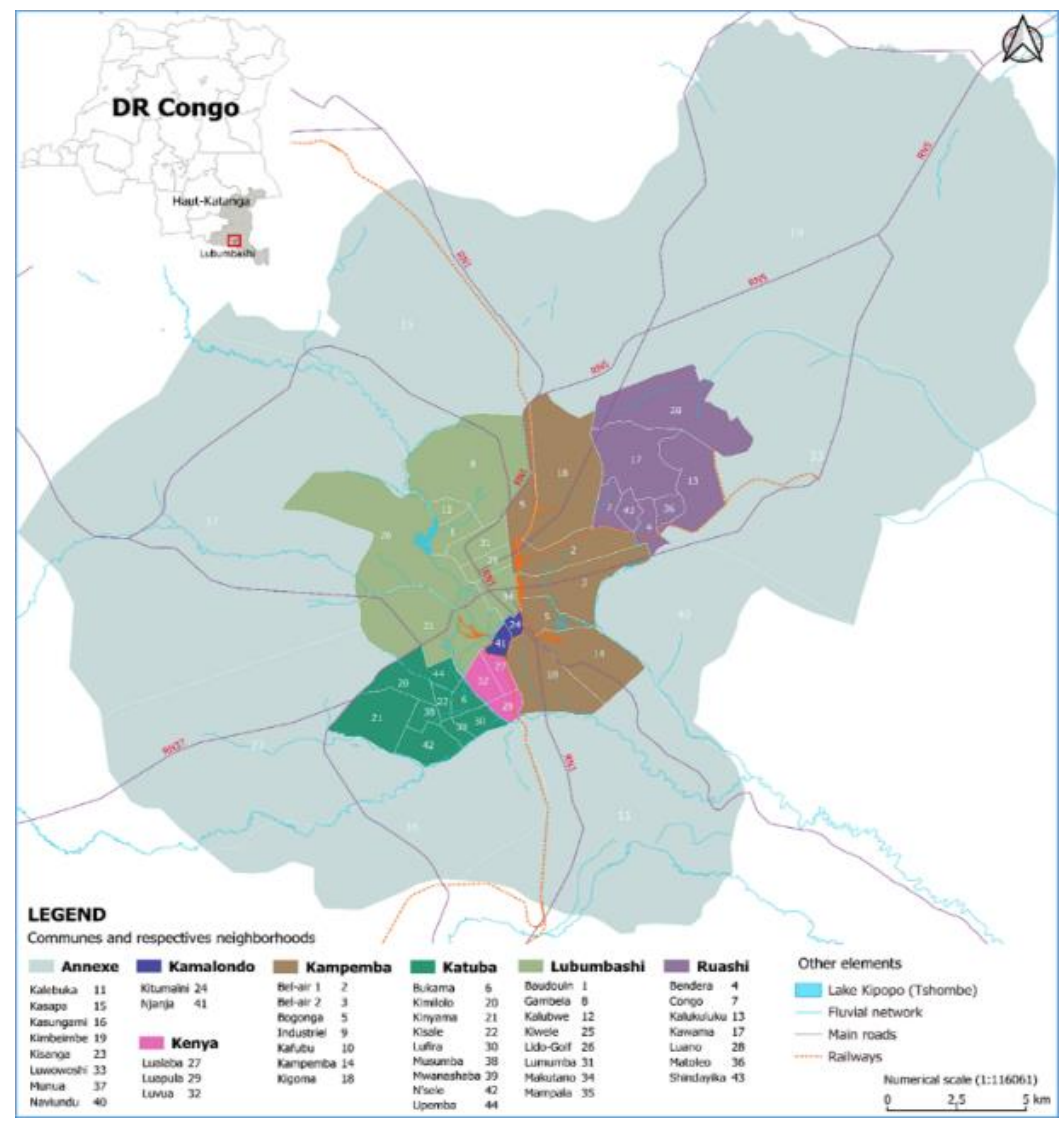

Figure 1 Administrative map of the Lubumbashi city (Map generated with the Qgis 3.16.1 Hannover software)

\subsection{Questionnaire and data collection}

A 30-items questionnaire was programmed online with the SurveyHeart 4.2 mobile application (https://www.surveyheart.com/). This questionnaire was composed in 3 sections, written in French, and respectively concerning knowledge (Table 2), attitudes (Table 3) and practices (Table 4) toward COVID-19. The online survey was preferred because of its ability to collect data without coming into contact with respondents [32], especially in the current conditions where the mobility of many people is reduced due to the second wave of the COVID-19 pandemic. The questionnaire was shared through personal contacts and social networking groups, that were identified in universities and schools, socio-cultural associations, as well as churches. The questionnaire has been programmed to receive only one response per respondent to avoid duplication. The comprehension of the survey questions was first tested on 20 people chosen at random, then the questionnaire was corrected on the basis of preliminary results. For data collection, the link to the questionnaire was activated from December 30, 2020 to January 21, 2021. People constituting the sample for this study were randomly self-selected, freely agreeing to answer the online questionnaire. It is important to stress that the inaccessibility of people who do not have smartphones or do not have access to the network connection, as well as people unable to read and/or understand the questions is a major limitation presented by the methodology of this study.

\subsection{Ethical considerations}

This study was approved by the Faculty of Pharmaceutical Sciences of the University of Lubumbashi and was conducted according to the ethical guidelines of the Helsinki Declaration [33]. Anyone who received the questionnaire link was free to participate or not in this survey. An explanatory note was added at the beginning of the questionnaire to allow those asked to understand the objectives of the study and the policy on the use of the data, in order to consent or not to participate. 


\subsection{Data processing}

\subsubsection{Verification}

At the end of the survey, the questionnaire link was deactivated, and the data table was downloaded as a Microsoft Excel file, in xlsx format. The variable "Residence address" was used to identify responses from outside the study area. Thus, responses from people living outside the Lubumbashi city, and the questionnaires Completed to less than 50\% were excluded from the database. From 521 questionnaires received during the survey, 18 that came outside the study area and 16 that were completed to less than $50 \%$, were discarded, which gave a total of 487 questionnaires retained for the statistical analyzes.

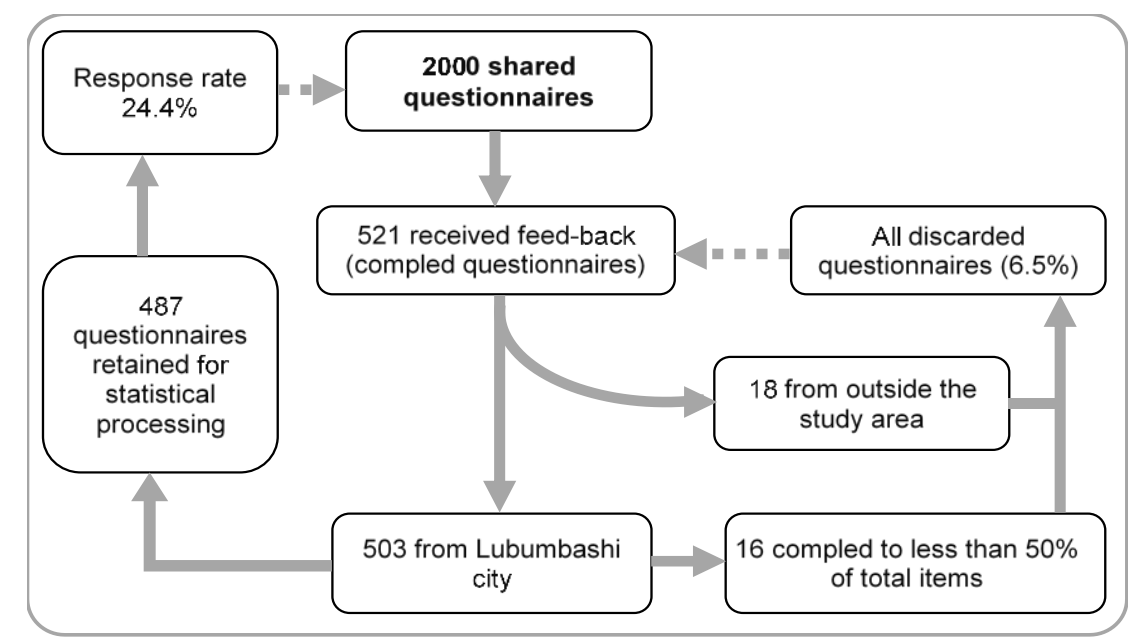

Figure 2 Data collection and verification scheme

\subsubsection{Statistical analysis}

Descriptive statistics were used for the quantification of modalities of qualitative variables and description of quantitative data, as well as their presentation in the frequency tables and graphs. The comparison of the proportions and the correlation tests between the qualitative variables were carried out with the chi-square test and the exact Fischer test. The different combinations of medicinal plants, drugs and honey in some recipes recommended by the respondents were shown in the form of a network graph (Figure 3), generated with Cytoscape 3.8 .2 (https://cytoscape.org/) software, with Organic layout [34, 35]. The Z test was used to compare the means age between males and females, and each of these groups with the total sample. Descriptive analyzes and statistical tests were carried out with XLSTAT 2020.5.1.1048, in the confidence and the significance level set at 0.95 and 0.05 respectively.

\section{Results}

\subsection{Characteristics of the surveyed people}

The 487 people who participated in this study are in the statistically comparable proportions $(p=0.834)$ between women and men (Table 1). This population is on average $28.3 \pm 7.7$ (95\% CI = $27.6-29.0$ ) years old and predominated by people between 20 and 30 years old, while the youngest and oldest are respectively 15 and 70 years old. The mean age of the total sample and that of women $(25.8 \pm 6.2$ years; $95 \% \mathrm{CI}=25.1-26.6)$, are significantly lower $(p<0.0001)$ than that of men $(31 \pm 8.2$ years; $95 \% \mathrm{CI}=29.9-32.0)$. Study level is dominated by academics $(54 \%)$, and marital status by married (49.5\%) and single (47.2\%). The intersection between gender and educational level showed a statistically significant correlation $(p<0.0001)$. In fact, all the people at the primary level are women, those at the secondary level are predominantly women $(71.1 \% ; n=211)$, while academics are mostly men $(65.8 \% ; n=263)$. The professions exercised by the resource persons are diverse, but it emerged that some of the people interviewed were still pupils or students, while other people declared that they did not exercise any profession at the time of the survey. It is also important to point out that a significant number (25.1\%) of people surveyed did not answer the question concerning their professions or occupations. The surveyed people live in all the communes of the Lubumbashi city, in the proportions shown in the Table 1. The tribal belonging of the surveyed people is marked by the presence of 52 tribes, from both Haut-Katanga and other provinces of DR Congo. Three most represented tribes are notably the Luba Kat (21.2\%), Bemba (15.8\%) and Lunda (13.8\%). 
Table 1 Sociodemographic information of resource persons.

\begin{tabular}{|c|c|c|c|}
\hline Variables & Modalities & $\mathbf{n}$ & $\%$ \\
\hline \multirow{2}{*}{ Gender } & Female & 247 & 50.7 \\
\hline & Male & 231 & 49.3 \\
\hline \multirow{7}{*}{ Age } & Less than 20 years old & 12 & 2.5 \\
\hline & 20 to 30 years & 327 & 67.1 \\
\hline & 31 to 40 years & 110 & 22.6 \\
\hline & 41 to 50 years & 19 & 3.9 \\
\hline & 51 to 60 years & 7 & 1.4 \\
\hline & 61 years and more & 3 & 0.6 \\
\hline & No answer & 9 & 1.8 \\
\hline \multirow[t]{5}{*}{ Marital status } & Married & 241 & 49.5 \\
\hline & Single & 230 & 47.2 \\
\hline & Widow & 8 & 1.6 \\
\hline & Divorced & 6 & 1.2 \\
\hline & No answer & 2 & 0.4 \\
\hline \multirow[t]{4}{*}{ Study level } & \begin{tabular}{|l|} 
Primary \\
\end{tabular} & 10 & 2.1 \\
\hline & Secondary & 211 & 43.3 \\
\hline & Academic & 263 & 54.0 \\
\hline & No answer & 3 & 0.6 \\
\hline \multirow{6}{*}{$\begin{array}{l}\text { Profession or occupation at the } \\
\text { time of the survey }\end{array}$} & Pupil & 7 & 1.4 \\
\hline & Student & 74 & 15.2 \\
\hline & Medical professions & 96 & 19.7 \\
\hline & Other professions & 147 & 30.2 \\
\hline & No occupation & 41 & 8.4 \\
\hline & No answer & 122 & 25.1 \\
\hline \multirow[t]{10}{*}{ Tribes } & Luba Katanga & 103 & 21.2 \\
\hline & Bemba & 77 & 15.8 \\
\hline & Lunda & 67 & 13.8 \\
\hline & Luba Kasaï & 59 & 12.1 \\
\hline & Tshokwe & 27 & 5.5 \\
\hline & Hemba & 12 & 2.5 \\
\hline & Lamba & 7 & 1.4 \\
\hline & Fuliru & 7 & 1.4 \\
\hline & Other tribes (44) & 89 & 18.3 \\
\hline & No answer & 39 & 8.0 \\
\hline \multirow{7}{*}{$\begin{array}{l}\text { Residential communes at the } \\
\text { time of the survey }\end{array}$} & Annexe & 93 & 19.1 \\
\hline & Kamalondo & 11 & 2.3 \\
\hline & Kampemba & 88 & 18.1 \\
\hline & Katuba & 92 & 18.9 \\
\hline & Kenya & 21 & 4.3 \\
\hline & Lubumbashi & 94 & 19.3 \\
\hline & Ruashi & 88 & 18.1 \\
\hline
\end{tabular}

\subsection{Knowledge}

Almost all of the surveyed people (98.2\%) said they were aware of the COVID-19. Academics $(97.7 \% ; n=263)$ and people with secondary education $(99.1 \%$; $\mathrm{n}=221)$, are the most likely to claim this knowledge, compared to those at primary level $(p=0.003)$. Several information sources on the COVID-19 have been cited and are predominantly on television (42.7\%) (Table 2). The chi-square test showed a significant correlation $(p<0.0001)$ between the study levels of the surveyed people and the information sources they used. So, Table 2 shows that academics mostly used television and the internet, while people with secondary education, used mostly the television and social networks; and those with primary level mostly exploited friends and social media. 
Table 2 Knowledge of people investigated on COVID-19

\begin{tabular}{|c|c|c|c|c|c|c|c|c|c|c|}
\hline \multirow{2}{*}{ Variables } & \multirow{2}{*}{ Modalities } & \multicolumn{2}{|c|}{$\begin{array}{l}\text { Total } \\
\text { sample }\end{array}$} & \multicolumn{3}{|c|}{$\begin{array}{l}\text { \% according to the } \\
\text { gender }\end{array}$} & \multicolumn{4}{|c|}{$\%$ according to the study level } \\
\hline & & $\mathbf{n}$ & $\%$ & $\begin{array}{l}\mathrm{F} \\
\mathrm{n}=\mathbf{2 4 7}\end{array}$ & $\begin{array}{l}\mathrm{M} \\
\mathrm{n}=231\end{array}$ & $\chi^{2}$ & $\begin{array}{l}\mathrm{PR} \\
\mathrm{n}=10\end{array}$ & $\begin{array}{l}\mathrm{SE} \\
\mathrm{n}=\mathbf{2 1 1}\end{array}$ & $\begin{array}{l}\mathrm{UN} \\
\mathrm{n}=263\end{array}$ & $\chi^{2}$ \\
\hline \multirow[t]{2}{*}{ Knowledge } & Yes & 478 & 98.2 & 98.8 & 97.4 & \multirow[b]{2}{*}{ ns } & 90.0 & 99.1 & 97.7 & \multirow{2}{*}{$* *$} \\
\hline & No & 9 & 1.8 & 1.2 & 2.6 & & 10.0 & 0.9 & 2.3 & \\
\hline \multirow{7}{*}{$\begin{array}{l}\text { Information } \\
\text { sources }\end{array}$} & Television & 208 & 42.7 & 48.2 & 36.8 & \multirow{7}{*}{$*$} & 20.0 & 48.8 & 39.2 & \multirow{7}{*}{$* * *$} \\
\hline & Social networks & 124 & 25.5 & 29.2 & 21.4 & & 30.0 & 28.4 & 28.4 & \\
\hline & Websites & 77 & 15.8 & 9.1 & 23.1 & & 0.0 & 6.2 & 24.3 & \\
\hline & Friends & 22 & 4.5 & 4.0 & 5.1 & & 30.0 & 5.2 & 3.0 & \\
\hline & Radio & 20 & 4.1 & 2.8 & 5.6 & & 0.0 & 2.8 & 5.3 & \\
\hline & Family members & 20 & 4.1 & 5.5 & 2.6 & & 20.0 & 7.1 & 0.8 & \\
\hline & Newspaper & 16 & 3.3 & 1.2 & 5.6 & & 0.0 & 1.4 & 4.9 & \\
\hline \multirow[t]{3}{*}{ Infection type } & Viral & 385 & 79.1 & 77.5 & 80.8 & \multirow{3}{*}{ ns } & 60.0 & 73.0 & 87.2 & \multirow{3}{*}{ *** } \\
\hline & Bacterial & 61 & 12.5 & 12.6 & 12.4 & & 0.0 & 15.2 & 11.0 & \\
\hline & No idea & 41 & 8.4 & 9.9 & 6.8 & & 40.0 & 11.8 & 3.8 & \\
\hline \multirow{6}{*}{$\begin{array}{l}\text { Means of } \\
\text { transmission }\end{array}$} & Respiratory droplets & 281 & 57.7 & 49.0 & 67.1 & \multirow{6}{*}{$* *$} & 0.0 & 40.8 & 73.7 & \multirow{6}{*}{$* * *$} \\
\hline & $\begin{array}{lll}\begin{array}{l}\text { Contact } \\
\text { objects }\end{array} & \text { with contaminated } \\
\end{array}$ & 81 & 16.6 & 15.4 & 17.9 & & 10.0 & 19.9 & 14.4 & \\
\hline & $\begin{array}{l}\text { Close contact with the infected } \\
\text { person }\end{array}$ & 72 & 14.8 & 19.4 & 9.8 & & 60.0 & 19.4 & 9.5 & \\
\hline & No idea & 46 & 9.4 & 14.6 & 3.8 & & 30.0 & 16.6 & 2.3 & \\
\hline & Contaminated water & 5 & 1.0 & 0.8 & 1.3 & & 0.0 & 2.4 & 0.0 & \\
\hline & Contaminated food & 2 & 0.4 & 0.8 & 0.0 & & 0.0 & 0.9 & 0.0 & \\
\hline \multirow{4}{*}{$\begin{array}{l}\text { Incubation } \\
\text { time }\end{array}$} & 1 to 14 days & 318 & 65.3 & 62.8 & 67.9 & \multirow{4}{*}{ ns } & 20.0 & 55.0 & 75.2 & \multirow{4}{*}{$* * *$} \\
\hline & 3 à 7 days & 46 & 9.4 & 11.1 & 7.7 & & 20.0 & 12.3 & 6.8 & \\
\hline & More than 14 days & 46 & 9.4 & 5.9 & 13.2 & & 0.0 & 6.6 & 12.2 & \\
\hline & No idea & 77 & 15.8 & 20.2 & 11.1 & & 60.0 & 20.1 & 5.7 & \\
\hline \multirow{6}{*}{$\begin{array}{l}\text { Main clinical } \\
\text { manifestations }\end{array}$} & Fever, headache and dry cough & 336 & 69.0 & 69.6 & 68.4 & & 30.0 & 57.8 & 80.2 & \\
\hline & $\begin{array}{l}\text { Shortness of breath and difficulty } \\
\text { in breathing }\end{array}$ & 100 & 20.5 & 16.6 & 24.8 & & 40.0 & 27.0 & 14.8 & \\
\hline & Tired & 12 & 2.4 & 3.2 & 1.7 & ns & 20.0 & 2.8 & 1.5 & $* * *$ \\
\hline & Stuffy nose with discharge & 11 & 2.3 & 3.4 & 0.9 & & 0.0 & 4.7 & 0.4 & \\
\hline & Sore throat and myalgia & 5 & 1.0 & 1.2 & 0.9 & & 0.0 & 0.9 & 1.1 & \\
\hline & No idea & 23 & 4.7 & 5.9 & 3.4 & & 10.0 & 6.6 & 1.9 & \\
\hline Most sensitive & Old & 249 & 51.1 & 49.8 & 52.6 & & 50.0 & 41.2 & 59.3 & \\
\hline people & Everyone & 123 & 25.3 & 24.9 & 25.6 & & 50.0 & 34.1 & 17.4 & \\
\hline & People with other diseases & 66 & 13.5 & 13.0 & 14.1 & & 0.0 & 12.3 & 14.8 & \\
\hline & Old and young & 22 & 4.5 & 5.1 & 5.1 & ns & 0.0 & 2.4 & 6.5 & $*$ \\
\hline & Young & 9 & 1.8 & 3.4 & 0.0 & & 0.0 & 0.0 & 0.0 & \\
\hline & Young adults & 3 & 0.6 & 0.4 & 0.9 & & 0.0 & 0.5 & 0.8 & \\
\hline & No idea & 15 & 3.1 & 4.3 & 1.7 & & 0.0 & 5.2 & 1.1 & \\
\hline Most affected & Respiratory & 380 & 78.0 & 71.9 & 84.6 & & 40.0 & 57.3 & 96.6 & \\
\hline organ system & Cardiovascular & 15 & 3.1 & 5.5 & 0.4 & & 0.0 & 6.6 & 0.4 & \\
\hline & Digestive & 9 & 1.8 & 2.4 & 1.3 & & 0.0 & 2.8 & 1.1 & \\
\hline & Muscular & 5 & 1.0 & 0.4 & 1.7 & $*$ & 0.0 & 0.9 & 1.1 & $* * *$ \\
\hline & Nervous & 3 & 0.6 & 0.4 & 0.9 & & 0.0 & 1.4 & 0.0 & \\
\hline & Genitourinary & 1 & 0.2 & 0.4 & 0.0 & & 10.0 & 0.0 & 0.0 & \\
\hline & No idea & 74 & 15.2 & 19.0 & 11.1 & & 50.0 & 30.8 & 0.8 & \\
\hline Do you feel & Yes & 310 & 63.7 & 55.3 & 72.7 & & 30.0 & 53.6 & 73.8 & \\
\hline $\begin{array}{l}\text { informed } \\
\text { about COVID- } \\
19 ?\end{array}$ & No & 177 & 36.3 & 44.7 & 27.3 & $*$ & 70.0 & 46.4 & 26.2 & $* * *$ \\
\hline
\end{tabular}

$\mathrm{F}=$ females; $\mathrm{M}=$ males; $\chi^{2}=$ appreciation of the correlation (with the chi-square test); ns = non-significant correlation $(p \geq 0.05) ;{ }^{*}=$ significant correlation $(p<0.05) ;{ }^{* *}=$ very significant correlation $(p<0.005) ;{ }^{* * *}=$ very highly significant correlation $(p<0.0005)$; $\mathrm{PR}=$ primary; SE = secondary; $\mathrm{UN}=$ academic

COVID-19 is essentially known as a viral infection (79.1\%). Statistically significant correlations $(p<0.0001)$ were observed between good knowledge of the causal agent and level of study, as well as the used information source. This good knowledge of the causal agent was found among people with secondary education (73.0\%) and academics $(87.2 \%)$, as well as those who obtained information from websites $(92.2 \% ; n=77)$, television $(87.0 \%$; $n=208)$, and 
newspapers $(81.3 \% ; \mathrm{n}=16)$. The main transmission route of COVID-19 was cited by $57.7 \%$, as respiratory droplets. Men are the most $(67.1 \% ; \mathrm{n}=231)$ to have this good information compared to women $(49.0 \% ; \mathrm{n}=247)(p<0.0001)$. According to the source of information, the good knowledge was provided in essentially by newspapers (93.8\%), and websites $(84.4 \%)(p<0.0001)$. Compared to study levels, academics are the most likely $(73.3 \%)$ to have the correct information on the main transmission route $(p<0.0001)$.

According to most of resource people (67.5\%), the incubation period for COVID-19 is from 1 to 14 days. It is also important to mention that a sizeable fraction (15.8\%) of resource persons said they had no idea how long this infection should incubate. The correct knowledge on the incubation time (1 to 14 days), was observed mostly $(p<0.0001)$ among academics and people who exploited websites (79.2\%), newspapers (75.0\%), and television (73.1\%) as information source. In addition, people not knowing this information are predominantly people with primary education level $(60.0 \% ; n=10)$ and those whose information on the COVID-19 has been given by family members $(75.0 \% ; n=20)$.

The first clinical manifestations of COVID-19 were cited by the majority $(69.0 \%)$ of resource persons as being fever, headache and dry cough. The correlation of this knowledge with the study level and the information source is statistically significant $(p<0.0001)$. This correlation has shown that academics and those who have been informed by newspapers, and websites are the most likely to have the right knowledge about this. According to $51.1 \%$ of informants, the old are the most susceptible to COVID-19 compared to other categories of the population. The chi-square test showed that academics are the most likely (59.3\%; $p=0.038)$ to know the category of people most susceptible to COVID19 , and that newspapers were found to be the majority source $(87.5 \% ; p<0.0001)$ of correct information about this. The respiratory system was cited by $78 \%$ of informants as the organ system affected by COVID-19 infection. Men $(84.6 \%)$ are the most numerous $(p=0.029)$ to have this good knowledge compared to women (71.9\%). Compared to study levels, academics (96.6\%) are in a significant majority $(p<0.0001)$, among those who have good knowledge of the organ system concerned. In addition, newspapers (100\%) and websites (98.7\%), turned out to be the majority sources $(p<0.0001)$ of good information on the organ system affected by COVID-19. Despite their knowledge and information sources, $63.7 \%$ of all resource people said that they feel sufficiently informed about the COVID-19, while $36.3 \%$ have acquired insufficient information regarding the aforementioned disease. Men (72.7\%) were significantly in the majority ( $p=0.010)$ among those feeling sufficiently informed. Academics $(73.8 \%)$ and those who have been informed through newspapers $(75.5 \%)$ and radio $(75.0 \%)$ are also predominant $(p<0.0001)$ among people who feel informed about the COVID-19; compared respectively with people of other study levels and those used other information sources.

\subsection{Attitudes}

With regard to the knowledges about COVID-19 observed in the surveyed population, Table 3 shows the results related to attitudes towards this disease. Most (71.9\%) of the surveyed population admitted to being afraid by the human-tohuman transmission of COVID-19. This attitude is comparable for men and women $(p=0.842)$; while it varies significantly depending on the study level $(p=0.002)$. People with secondary education $(75.4 \%)$ and academics $(70.4 \%)$ are said to be more frightened than people with primary education (50.0\%). About $3 / 4(72.1 \%)$ of the surveyed population hope that the COVID-19 pandemic can stop and return to normal life. This hope was mainly ( $p<0.0001)$ observed in men (78.6\%) compared to women (66.0\%). Academics are also the most likely $(p<0.0001)$ to hope for the end of the COVID-19 pandemic, compared to people at other study levels. A significant fraction (61.8\%) of the total sample feel able of supporting the emergence of this pandemic. This feeling did not show any variation with the gender or the study level of those surveyed. It is important to mention that a small proportion (32.6\%) of the surveyed population admitted to being impacted in their lives by the COVID-19 pandemic. In relation to this attitude, no variation in proportion was statistically observed either in gender $(p=0.427)$ or the study level $(p=0.059)$.

Several elements were cited by resource people as a major concern regarding the COVID-19 pandemic. These concerns are predominantly family health (35.6\%) and the closure of schools and universities (16.2\%). The citation frequencies of these concerns do not vary significantly with gender $(p=0.213)$; whereas a significant variation was observed in relation to the studies levels $(p=0.026)$. Indeed, family health and the closure of schools and universities are predominant concerns among those with secondary education and academics, while family health and the closing of churches are predominant among those with a primary educational level (Table 3). Among the obstacles related to COVID-19, which are encountered by those surveyed, the curfew was the most cited (38.4\%) compared to several others. It should be noted that $16 \%$ of all resource persons declared having no obstacles in their life during the COVID19 pandemic. Significant variations were observed in relation to gender $(p<0.0001)$ and study levels $(p<0.0001)$. Beside the curfew, people who know no obstacles (26.5\%) predominate among women, while mass event cancellation predominates among men (25.1\%). In relation to the study level, the most of people with primary education (70.0\%) 
declared that they had no obstacles; while the curfew is the major obstacle for those with secondary education (62.1\%) and the cancellation of mass events, for academics (25.1\%).

Table 3 Information related to the attitudes of people surveyed, in relation to the COVID-19

\begin{tabular}{|c|c|c|c|c|c|c|c|c|c|c|}
\hline \multirow[t]{2}{*}{ Questions } & \multirow[t]{2}{*}{ Answers } & \multicolumn{2}{|c|}{$\begin{array}{l}\text { Total } \\
\text { sample }\end{array}$} & \multicolumn{3}{|c|}{$\begin{array}{l}\text { \% according to the } \\
\text { gender }\end{array}$} & \multicolumn{4}{|c|}{$\begin{array}{l}\text { \% according to the study } \\
\text { level }\end{array}$} \\
\hline & & $\mathbf{n}$ & $\%$ & $\mathbf{F}$ & $\mathbf{M}$ & $\chi^{2}$ & PR & SE & UN & $\chi^{2}$ \\
\hline \multirow{3}{*}{$\begin{array}{l}\text { Are you afraid of human-to- } \\
\text { human transmission of } \\
\text { COVID-19? }\end{array}$} & Yes & 350 & 71.9 & 70.4 & 73.5 & \multirow{3}{*}{ ns } & 50.0 & 75.4 & 70.4 & \multirow{3}{*}{$* *$} \\
\hline & No & 115 & 23.6 & 25.3 & 21.8 & & 40.0 & 19.0 & 26.2 & \\
\hline & I do not care & 22 & 4.5 & 4.3 & 4.7 & & 10.0 & 5.6 & 3.4 & \\
\hline \multirow{3}{*}{$\begin{array}{l}\text { Are you hoping the pandemic } \\
\text { will stop and return to normal } \\
\text { life? }\end{array}$} & Yes & 351 & 72.1 & 66.0 & 78.6 & \multirow{3}{*}{$* * *$} & 60.0 & 61.1 & 80.0 & \multirow{3}{*}{$* * *$} \\
\hline & No & 80 & 16.4 & 26.5 & 5.6 & & 20.0 & 29.9 & 5.7 & \\
\hline & I am not sure & 56 & 11.5 & 7.5 & 15.8 & & 20.0 & 9.0 & 13.3 & \\
\hline \multirow{4}{*}{$\begin{array}{l}\text { Do you think you can handle } \\
\text { the emergence of the COVID- } \\
19 \text { pandemic in your lifetime? }\end{array}$} & Yes & 301 & 61.8 & 69.6 & 53.4 & \multirow{4}{*}{ ns } & 60.0 & 68.7 & 55.9 & \multirow{4}{*}{ ns } \\
\hline & No & 127 & 26.1 & 23.3 & 29.1 & & 20.0 & 18.0 & 33.1 & \\
\hline & I am not sure & 57 & 11.7 & 7.1 & 16.7 & & 20.0 & 12.3 & 11.0 & \\
\hline & No answer & 2 & 0.4 & 0.0 & 0.9 & & 0.0 & 0.9 & 0.0 & \\
\hline \multirow{2}{*}{$\begin{array}{l}\text { Has the COVID-19 pandemic } \\
\text { had an impact on your daily } \\
\text { life? }\end{array}$} & Yes & 437 & 89.7 & 88.1 & 91.5 & \multirow[b]{2}{*}{ ns } & 80.0 & 88.6 & 90.9 & \multirow[b]{2}{*}{ ns } \\
\hline & No & 50 & 10.3 & 11.9 & 8.5 & & 20.0 & 11.4 & 9.1 & \\
\hline \multirow{6}{*}{$\begin{array}{l}\text { What would be your major } \\
\text { concern about the Covid-19 } \\
\text { pandemic? }\end{array}$} & Family health & 159 & 32.6 & 36.0 & 34.2 & \multirow{6}{*}{ ns } & 40.0 & 23.7 & 38.8 & \multirow{6}{*}{ * } \\
\hline & $\begin{array}{l}\text { Closure of schools and } \\
\text { universities }\end{array}$ & 157 & 32.2 & 31.2 & 28.2 & & 10.0 & 46.0 & 22.4 & \\
\hline & My own health & 88 & 18.1 & 15.4 & 20.9 & & 0.0 & 12.3 & 23.6 & \\
\hline & Closing of churches & 40 & 8.2 & 7.1 & 9.4 & & 20.0 & 6.6 & 9.1 & \\
\hline & Nothing worries me & 32 & 6.6 & 9.1 & 3.8 & & 30.0 & 10.4 & 2.7 & \\
\hline & Be quarantined & 11 & 2.3 & 1.2 & 3.4 & & 0.0 & 0.9 & 3.4 & \\
\hline \multirow{8}{*}{$\begin{array}{l}\text { What is the biggest obstacle in } \\
\text { your daily life during the } \\
\text { COVID-19 pandemic? }\end{array}$} & Curfew & 187 & 38.4 & 48.2 & 27.8 & \multirow{8}{*}{$* * *$} & 20.0 & 62.1 & 20.5 & \multirow{8}{*}{$* * *$} \\
\hline & $\begin{array}{l}\text { Cancellation of mass } \\
\text { events }\end{array}$ & 79 & 16.2 & 7.9 & 25.2 & & 0.0 & 6.1 & 25.1 & \\
\hline & No obstacle & 78 & 16.0 & 26.5 & 4.7 & & 70.0 & 24.2 & 6.5 & \\
\hline & $\begin{array}{l}\text { Difficulty getting to } \\
\text { work }\end{array}$ & 49 & 10.1 & 5.9 & 14.5 & & 10.0 & 0.9 & 17.5 & \\
\hline & $\begin{array}{l}\text { Lack of protective } \\
\text { equipment }\end{array}$ & 42 & 8.6 & 6.3 & 11.1 & & 0.0 & 2.8 & 13.7 & \\
\hline & Price increase & 25 & 5.1 & 3.0 & 7.7 & & 0.0 & 1.9 & 8.0 & \\
\hline & Cancellation of trips & 19 & 3.9 & 2.0 & 5.9 & & 0.0 & 0.5 & 6.8 & \\
\hline & Lack of foods & 8 & 1.6 & 0.3 & 3.0 & & 0.0 & 1.4 & 1.9 & \\
\hline
\end{tabular}

$\mathrm{F}=$ females; $\mathrm{M}=$ Males; $\mathrm{PR}=$ primary; $\mathrm{SE}=$ secondary; UN = academic, $\chi^{2}=$ appreciation of the correlation; ns = non-significant correlation $(p \geq$ $0.05) ;{ }^{*}=$ significant correlation $(p<0.05) ;{ }^{* *}=$ very significant correlation $(p<0.005) ;{ }^{* * *}=$ very highly significant correlation $(p<0.0005)$.

\subsection{Practices}

To protect against contamination with COVID-19, several practices were cited by the surveyed people. These practices are predominated by the combination of wearing surgical mask, distancing and washing hands. The citation frequencies of different protection practices vary significantly $(p<0.0001)$ with gender and study level. Women also cited staying at home (16.2\%), in addition to wearing a surgical mask, distance and hand washing (47.4\%), which remain very much preferred by men $(88.0 \%)$. A significant number $(40.0 \%)$ of people with primary education reported that they do not take any special measures to protect against COVID-19. In contrast, most people with a secondary education (41.7\%) and academics (69.1\%) reported that they combine wearing a surgical mask, distancing and the hands washing.

In the presence of symptoms related to COVID-19, the surveyed population recommends various practices (Table 4). Self-medication with medicinal plants is the sole practice for most (52.8\%) of surveyed people. It is also important to note that $4.1 \%$ recommended self-medication with conventional drugs (Table 5). Self-medication with medicinal plants is also recommended by $65.1 \%$ of those who prefer to stay at home $(\mathrm{n}=82), 38.9 \%$ of those who prefer to go to a hospital $(\mathrm{n}=126)$ and $10 \%$ of those who prefer self-medication with conventional drugs $(\mathrm{n}=10)$; which gives a total of $70.6 \%$ of people advocating taking herbal remedies to fight the symptoms of COVID-19, among total sample. In total, 21 species of medicinal plants (Table 5) and 17 conventional drugs (Table 6) were cited. Plants are predominantly 
Table 4 Measures taken or envisaged by the surveyed people

\begin{tabular}{|c|c|c|c|c|c|c|c|c|c|c|}
\hline \multirow[t]{2}{*}{ Questions } & \multirow[t]{2}{*}{ Answers } & \multicolumn{2}{|c|}{$\begin{array}{l}\text { Total } \\
\text { sample }\end{array}$} & \multicolumn{3}{|c|}{$\begin{array}{l}\text { \% according to the } \\
\text { gender }\end{array}$} & \multicolumn{4}{|c|}{$\begin{array}{l}\text { \% according to the study } \\
\text { level }\end{array}$} \\
\hline & & $\mathbf{n}$ & $\%$ & $\mathbf{F}$ & $\mathbf{M}$ & $\chi^{2}$ & PR & SE & UN & $\chi^{2}$ \\
\hline \multirow{8}{*}{$\begin{array}{l}\text { What are you doing to } \\
\text { protect yourself from } \\
\text { contamination with the } \\
\text { Covid-19 virus? }\end{array}$} & $\begin{array}{l}\text { Wearing a surgical mask, } \\
\text { distancing, washing hands }\end{array}$ & 326 & 66.9 & 47.4 & 88.0 & \multirow{8}{*}{$* * *$} & 20.0 & 41.7 & 69.1 & \multirow{8}{*}{$* * *$} \\
\hline & Stay at home & 45 & 9.2 & 16.2 & 1.7 & & 20.0 & 19.1 & 20.6 & \\
\hline & No special practice & 44 & 9.0 & 12.3 & 5.6 & & 40.0 & 12.3 & 4.1 & \\
\hline & Regular hand washing & 35 & 7.2 & 12.6 & 1.3 & & 20.0 & 13.7 & 2.3 & \\
\hline & Keep the right distance & 23 & 4.7 & 8.3 & 0.9 & & 0.0 & 9.0 & 0.8 & \\
\hline & Cover the mouth to cough & 6 & 1.2 & 2.3 & 0.0 & & 0.0 & 2.4 & 0.4 & \\
\hline & HEPA filter mask wearing & 5 & 1.0 & 0.4 & 1.7 & & 0.0 & 0.5 & 1.5 & \\
\hline & Take alcohol & 3 & 0.6 & 0.4 & 0.9 & & 0.0 & 1.4 & 0.0 & \\
\hline \multirow{5}{*}{$\begin{array}{l}\text { What would you do if } \\
\text { you had symptoms } \\
\text { associated with Covid- } \\
19 ?\end{array}$} & Take medicinal plants & 257 & 52.8 & 65.6 & 38.9 & \multirow{5}{*}{$* * *$} & 70.0 & 78.7 & 30.8 & \multirow{5}{*}{$* * *$} \\
\hline & Go to the hospital & 126 & 25.8 & 17.8 & 34.6 & & 10.0 & 10.0 & 39.5 & \\
\hline & Stay at home & 82 & 16.8 & 11.9 & 22.2 & & 20.0 & 6.6 & 25.1 & \\
\hline & Take the drugs & 20 & 4.1 & 4.7 & 3.4 & & 0.0 & 4.3 & 4.1 & \\
\hline & I do not know what to do & 2 & 0.4 & 0.0 & 0.9 & & 0.0 & 0.5 & 0.4 & \\
\hline \multirow{4}{*}{$\begin{array}{l}\text { Are you ready to help } \\
\text { with the front line } \\
\text { rescue? }\end{array}$} & Yes & 257 & 52.8 & 38.3 & 68.4 & \multirow{4}{*}{$* * *$} & 40.0 & 50.7 & 70.7 & \multirow{4}{*}{$* * *$} \\
\hline & No & 126 & 33.3 & 42.3 & 23.5 & & 60.0 & 31.8 & 18.6 & \\
\hline & I need the family advice & 57 & 11.7 & 15.0 & 8.1 & & 0.0 & 14.2 & 10.3 & \\
\hline & No answer & 11 & 2.3 & 4.3 & 0.0 & & 0.0 & 3.3 & 0.4 & \\
\hline \multirow{6}{*}{$\begin{array}{l}\text { What would you do if } \\
\text { you had direct contact } \\
\text { with one or more } \\
\text { infected people? }\end{array}$} & Take medicinal plants & 150 & 30.8 & 44.2 & 16.2 & \multirow{6}{*}{$* * *$} & 70.0 & 45.0 & 18.3 & \multirow{6}{*}{$* * *$} \\
\hline & Contact the response team & 154 & 29.8 & 15.4 & 45.2 & & 0.0 & 4.2 & 51.7 & \\
\hline & Take the drugs & 94 & 19.3 & 17.0 & 22.0 & & 0.0 & 30.8 & 11.0 & \\
\hline & Go to the hospital & 73 & 15.0 & 17.4 & 12.4 & & 30.0 & 15.2 & 13.3 & \\
\hline & Talk to those around me & 17 & 3.5 & 4.0 & 2.3 & & 0.0 & 2.8 & 4.2 & \\
\hline & I do not know what to do & 8 & 1.6 & 2.0 & 1.2 & & 0.0 & 1.9 & 1.5 & \\
\hline \multirow{3}{*}{$\begin{array}{l}\text { What would you do if } \\
\text { someone recovered } \\
\text { from COVID-19 seeks to } \\
\text { meet with you? }\end{array}$} & $\begin{array}{l}\text { I ask her to wear mask and no } \\
\text { direct contact }\end{array}$ & 339 & 69.6 & 68.4 & 70.9 & \multirow{3}{*}{ ns } & 20.0 & 71.1 & 70.0 & \multirow{3}{*}{$* * *$} \\
\hline & I meet like everyone else & 122 & 25.1 & 23.3 & 26.9 & & 50.0 & 22.3 & 26.6 & \\
\hline & I refuse to meet him & 26 & 5.3 & 8.3 & 2.1 & & 30.0 & 6.6 & 3.4 & \\
\hline \multirow{4}{*}{$\begin{array}{l}\text { What is your top } \\
\text { priority when the } \\
\text { pandemic can end? }\end{array}$} & Return to daily activities & 357 & 73.3 & 64.4 & 82.9 & \multirow{4}{*}{$*$} & 10.0 & 65.4 & 81.7 & \multirow{4}{*}{$* * *$} \\
\hline & No priority & 123 & 25.3 & 33.2 & 16.7 & & 90.0 & 33.6 & 16.4 & \\
\hline & $\begin{array}{lll}\text { Go live in another } \\
\text { environment }\end{array}$ & 2 & 0.4 & 0.4 & 0.4 & & 0.0 & 1.0 & 0.0 & \\
\hline & No answer & 5 & 1.0 & 2.0 & 0.0 & & 0.0 & 0.0 & 1.9 & \\
\hline
\end{tabular}

HEPA = High-Efficiency Particulate Air; F = woman; M = men; PR = primary; SE = secondary; UN = academic, $\chi^{2}=$ appreciation of the correlation with the chi-square test; ns $=$ non-significant correlation $(p \geq 0.05){ }^{*}=\operatorname{significant}$ correlation $(p<0.05) ;{ }^{* * *}=$ very highly significant correlation $(p$ $<0.0005)$.

Table 5 Medicinal plants recommended by 344 respondents, in case of possible symptoms related to COVID-19

\begin{tabular}{|c|c|c|c|c|c|c|}
\hline Accepted scientific name & Family & $\begin{array}{l}\text { Names used by } \\
\text { respondents }\end{array}$ & $\begin{array}{l}\text { Used } \\
\text { organs }\end{array}$ & $\mathbf{n}$ & $(\%)$ & $\begin{array}{l}\text { Anti-COVID-19 } \\
\text { potential } \\
\text { already } \\
\text { reported }\end{array}$ \\
\hline Eucalyptus globulus Labill. & Myrtaceae & Eucalyptus (French) & Leaves & 158 & 45.9 & Yes $[10,36]$ \\
\hline Cymbopogon citratus (DC.) Stapf. & Poaceae & $\begin{array}{l}\text { Citronelle (French) } \\
\text { Bwema (Luba) }\end{array}$ & Leaves & 131 & 38.1 & Yes $[10,36]$ \\
\hline Artemisia annua L. & Compositae & Artemisia (French) & Leaves & 77 & 22.4 & Yes [37] \\
\hline Allium sativum $\mathrm{L}$. & Amaryllidaceae & Ail (French) & Bulbs & 68 & 19.8 & Yes $[36,38]$ \\
\hline Zingiber officinale Roscoe. & Zingiberaceae & $\begin{array}{l}\text { Tangawisi (Swahili) } \\
\text { Gingembre (French) }\end{array}$ & Rhizome & 62 & 18.0 & Yes $[10,36,39]$ \\
\hline Citrus limon (L.) Osbeck. & Rutaceae & $\begin{array}{l}\text { Citronnier (French) } \\
\text { Mapela (Swahili) }\end{array}$ & $\begin{array}{l}\text { Fruit } \\
\text { Leaves }\end{array}$ & 49 & 14.2 & Yes $[10,36]$ \\
\hline Aloe vera (L.) Burm.f. & Xanthorrhoeaceae & Aloe (French) & Leaves & 17 & 4.9 & Yes [40] \\
\hline
\end{tabular}




\begin{tabular}{|c|c|c|c|c|c|c|}
\hline Accepted scientific name & Family & $\begin{array}{l}\text { Names used by } \\
\text { respondents }\end{array}$ & $\begin{array}{l}\text { Used } \\
\text { organs }\end{array}$ & $\mathbf{n}$ & (\%) & $\begin{array}{l}\text { Anti-COVID-19 } \\
\text { potential } \\
\text { already } \\
\text { reported }\end{array}$ \\
\hline Moringa oleifera Lam. & Moringaceae & Moringa (French) & Leaves & 8 & 2.3 & Yes [41] \\
\hline Tetradenia riparia (Hochst.) Codd & Lamiaceae & $\begin{array}{l}\text { Mutuzo (Swahili) } \\
\text { Ntubia (Bembe) }\end{array}$ & Leaves & 8 & 2.3 & Unfolded \\
\hline $\begin{array}{l}\text { Syzygium aromaticum (L.) Merr. } \\
\text { \& L.M.Perry. }\end{array}$ & Myrtaceae & Giroflier (French) & Flowers & 6 & 1.7 & Yes [10] \\
\hline $\begin{array}{l}\text { Gymnanthemum amygdalinum } \\
\text { (Delile) Sch.Bip. }\end{array}$ & Asteraceae & $\begin{array}{l}\text { Kongo bololo } \\
\text { (Lingala) }\end{array}$ & Leaves & 6 & 1.7 & Unfolded* \\
\hline $\begin{array}{l}\text { Dysphania ambrosioides (L.) } \\
\text { Mosyakin \& Clemants. }\end{array}$ & Amaranthaceae & Lufwanyuki (Luba) & $\begin{array}{l}\text { Aerial } \\
\text { part }\end{array}$ & 6 & 1.7 & Yes [42] \\
\hline Camellia sinensis (L.) Kuntze. & Theaceae & $\begin{array}{l}\text { Thé (French) } \\
\text { Chayi (Swahili) }\end{array}$ & Leaves & 6 & 1.7 & Yes [43] \\
\hline Carica papaya L. & Caricaceae & $\begin{array}{l}\text { Papaier (French) } \\
\text { Kipapayi (Swahili) }\end{array}$ & Leaves & 4 & 1.2 & Yes [38] \\
\hline Psidium guajava L. & Myrtaceae & $\begin{array}{l}\text { Goyavier (French) } \\
\text { Mapela (Swahili) }\end{array}$ & Leaves & 4 & 1.2 & Yes [44] \\
\hline Mangifera indica L. & Anacardiaceae & $\begin{array}{l}\text { Mangier (French) } \\
\text { Mwembe (Luba) }\end{array}$ & $\begin{array}{l}\text { Leaves or } \\
\text { Stem } \\
\text { bark }\end{array}$ & 3 & 0.9 & Yes [38] \\
\hline Mentha spicata L. & Lamiaceae & Menthe (French) & Leaves & 2 & 0.6 & Yes [10] \\
\hline Allium cepa $\mathrm{L}$. & Amaryllidaceae & $\begin{array}{l}\text { Oignon rouge } \\
\text { (French) }\end{array}$ & Bulbs & 2 & 0.6 & Yes [45] \\
\hline Persea americana Mill. & Lauraceae & Avocatier (French) & Leaves & 1 & 0.3 & Unfolded* \\
\hline Panax ginseng C.A.Mey. & Araliaceae & Ginseng (French) & Roots & 1 & 0.3 & Yes [46] \\
\hline Cinchona officinalis L. & Rubiaceae & Quinquina (French) & Leaves & 1 & 0.3 & Yes [47] \\
\hline
\end{tabular}

*Plants for which the anti-COVID-19 potential has not yet been reported but whose the use against this disease has been reported in the Gbado-Lite city (in northern DR Congo) [18].

Table 6 Conventional drugs recommended by 41 respondents, in the event of possible symptoms related to COVID-19

\begin{tabular}{|c|c|c|c|c|c|}
\hline $\begin{array}{l}\text { International Nonproprietary } \\
\text { Names }\end{array}$ & \begin{tabular}{|l|} 
Names used by \\
respondents c
\end{tabular} & Pharmacological class & $\mathbf{n}$ & $(\%)$ & $\begin{array}{l}\text { Use in the COVID-19 } \\
\text { management }\end{array}$ \\
\hline Acetylsalicylic acid & Aspirine & $\begin{array}{l}\text { Antipyretic Ani-inflammatory } \\
\text { and analgesic }\end{array}$ & 17 & 41.5 & Yes [48] \\
\hline Chloroquine & Chloroquine & Antimalarial & 15 & 36.6 & Yes [49] \\
\hline Azithromycin & \begin{tabular}{|l|} 
Azythromycine \\
\end{tabular} & Antibiotic & 11 & 26.8 & Yes $[9,50]$ \\
\hline Ascorbic acid & \begin{tabular}{|l|} 
Vitamine C \\
\end{tabular} & Vitamin and antioxidant & 7 & 17.1 & Yes $[9,51]$ \\
\hline Manacovid a & Manacovid $^{\circledR}$ & Antiviral & 6 & 14.6 & Yes [52] \\
\hline Paracetamol & \begin{tabular}{|l} 
Tremperie $^{\circledR}$, \\
Paracétamol \\
\end{tabular} & Antipyretic analgesic & 5 & 12.2 & Yes $[36,53]$ \\
\hline Artemether-Lumefantrine ${ }^{b}$ & Coartem $^{\circledR}$ & Antimalarial & 2 & 4.9 & Unfolded \\
\hline Zinc & Zinc & Trace element and antioxidant & 2 & 4.9 & Yes [54] \\
\hline Amoxicillin & Amoxicilline & Antibiotic & 1 & 2.4 & Unfolded \\
\hline Artesunante-Amodiaquine ${ }^{b}$ & $\mathrm{ASAQ}^{\circledR}$ & Antimalarial & 1 & 2.4 & Yes [55] \\
\hline Artesunate & Artesunate & Antimalarial & 1 & 2.4 & Yes $[56,57]$ \\
\hline Dexamethasone & Dexaméthasone & Steroidal Anti Inflammatory & 1 & 2.4 & Yes $[9,58]$ \\
\hline Heparin & Héparine & Anticoagulant & 1 & 2.4 & Yes [59] \\
\hline Ibuprofen-Paracetamol & Anaflam ${ }^{\circledR}$ & $\begin{array}{l}\text { Antipyretic Ani-inflammatory } \\
\text { and analgesic }\end{array}$ & 1 & 2.4 & Yes $[9,53]$ \\
\hline Quinine & Quinine & Antimalarial & 1 & 2.4 & Unfolded \\
\hline Thiamine & Vitamine B1 & Vitamin & 1 & 2.4 & Yes [60] \\
\hline
\end{tabular}

${ }^{a}$ A new anti-COVID-19 drug based on medicinal plants, made in DR Congo; ${ }^{\mathrm{b}}$ Artemisinin-based therapeutic association; $\mathrm{c}$ the names of conventional drugs have been cited in French 
Eucalyptus globulus Labill. (45.9\%; $\mathrm{n}=344)$, Cymbopogon citratus (DC.) Stapf. (38.1\%; $\mathrm{n}=344$ ) and Artemisia annua $\mathrm{L}$. $(22.4 \% ; \mathrm{n}=344)$; while conventional drugs are predominantly aspirin $(41.5 \% ; \mathrm{n}=41)$, chloroquine $(36.6 \% ; \mathrm{n}=41)$ and Azythromycin $(26.8 \% ; n=41)$. Medicinal plants have been cited as being used alone or in combinations of 2 to 5 plant species, between them and conventional drugs or between plant species and honey (Figure 3). It was found that selfmedication with conventional drugs was cited mainly $(p=0.032)$ by people from medical professions $(67.7 \% ; \mathrm{n}=96)$, while self-medication with medicinal plants showed no correlation with the type of the exercised profession $(p=0.784)$. Significant correlations $(p<0.0001)$ were observed between recommended practice to treat the COVID-19 symptoms and gender, as well as the studies level. Indeed, self-medication with medicinal plants is widely cited by women (65.6\%), against men who mainly cited self-medication with medicinal plants (38.9\%) and going to the hospital (34.6\%). People with secondary (78.7\%) and primary (70.0\%) education are the most likely to prefer self-medication with medicinal plants, compared to academics (30.8\%), among whom many preferred going to hospital in case of COVID-19 symptoms.

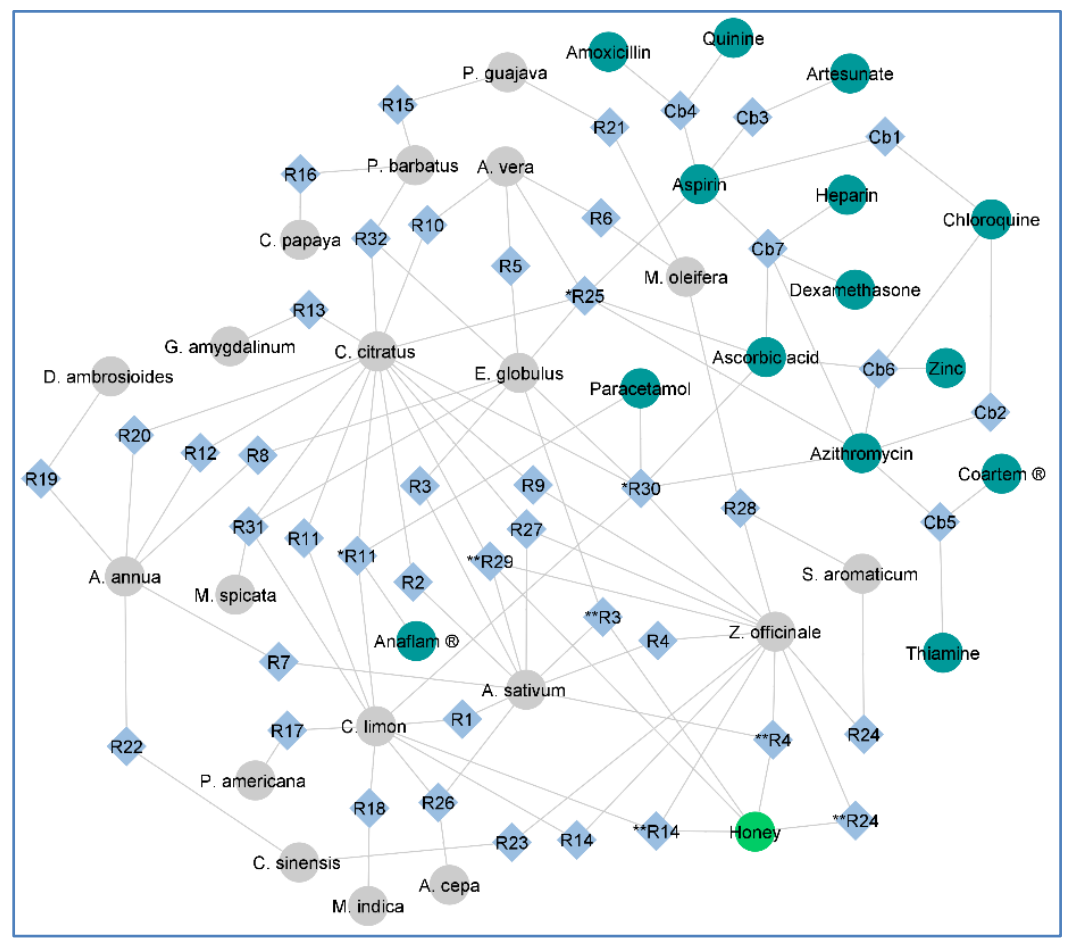

Figure 3 Types of combinations of medicinal plants, honey and conventional drugs, recommended by the people surveyed, in the event of possible symptoms related to COVID-19. Diamond-shaped knots represent types of combinations; with $\mathrm{Cb}=$ combination between conventional drugs; $\mathrm{R}=$ combination between medicinal plants; ${ }^{*} \mathrm{R}=$ combination between medicinal plants and conventional drugs and; ${ }^{* *} \mathrm{R}=$ Combination between medicinal plants and honey. The circle nodes represent the elements used in different types of combinations. With khaki circles = medicinal plants; bluish green = conventional drugs and; light green $=$ honey .

In the event that the official health system is overwhelmed by the excess number of COVID-19 cases, $52.8 \%$ of surveyed people said to be ready to help the nursing body, against $33.3 \%$ who said no to this question, $11.7 \%$ who need advice from their families and 2.3\% who did not answer. Men are significantly $(p<0.0001)$ the most numerous $(68.4 \%)$ to feel ready to help healthcare staff, in the event of the COVID-19 cases surplus. It was also found that the desire for intervention increases significantly $(p<0.0001)$ with the level of study, academics being the most numerous to declare themselves ready to intervene $(70.7 \%)$.

In the event of direct contact with a person infected with COVID-19, the recommended practices are predominant by self-medication with medicinal plants (30.8\%) and contacting the COVID-19 response team. Significant influence $(p<$ 0.0001 ) of gender on this question showed that women predominantly advocate self-medication with medicinal plants $(44.2 \%)$ and conventional drugs $(17.0 \%)$, while men recommend mainly contacting the response team (45.2\%) and self-medication with conventional drugs $(22.0 \%)$. Significant variability $(p<0.0001)$ was also observed in the responses grouped by the studies level. In fact, self-medication with medicinal plants is mainly recommended by people at primary $(70.0 \%)$ and secondary $(45.0 \%)$ levels, while the majority of academics recommend contacting the response team (51.7\%). In the event of a meeting requested by a person recovered from COVID-19, 69.6\% of resource persons would prefer to accept the meeting while asking the person recovered to wear the mask and avoiding direct contact. This 
practice is also preferred by the majority of people with secondary education and academics, against those with the primary level who would mostly prefer to meet the person cured of COVID-19 like everyone else. Furthermore, no significant correlation was observed at this question, according to gender $(p=0.139)$. To the extent that the COVID-19 pandemic ends, most (73.3\%) of surveyed people will be able to return to their daily activities. Among women, $64.4 \%$ preferred to return to daily activities, while $33.2 \%$ reported having no priority. A return to daily activities is the wish of the most surveyed men (82.9\%). This same wish was also observed among most informant with secondary education $(65.4 \%)$ and academics (81.7\%), compared to $10.0 \%$ of people with primary education. Most (90.0\%) of people in primary education said they had no priority.

\section{Discussion}

The evaluation of the population KAPs towards COVID-19 is a very important element for understanding the epidemiological evolution of this disease and planning of actions for an effective control [8]. Since the onset of the COVID-19 disease in DR Congo, no study has assessed the KAPs of the general population. This study reports the KAP of the population of Lubumbashi city, in relation to COVID-19.

The characteristics of the surveyed population (Table 1) are generally close to those of the Congolese population. The average age of less than 30 years observed in this study can be explained by the fact that Congolese population is mostly young, predominated by the people under 20 years old [61]. This population is also known to be slightly predominated by women [61], although their proportion is not statistically different from that of the men who participated in this survey. The average age observed in this study may also be due to the fact that young people are the most active on social networks [62], which were used for data collection. The predominance of high school students and academics in this study can be explained by the fact that most of them would use the Smartphone, they would be the most active on social networks and mostly able to read and understand the questionnaire which have been shared. Tribal diversity and proportions of the marital status observed, generally reflect the composition of the population of the Lubumbashi city. Indeed, this last population characterized by the presence of people from several territories across the province of HautKatanga and various provinces across the country [23]. The predominance of married and single people in the study area has been reported since 2014 by the National Institute of Statistics [61].

Table 2 showed that the surveyed population has an overall high knowledge about COVID-19. However, the numbers of people with the correct knowledge about COVID-19 vary significantly with the study level, gender and information source; with the best scores in higher education levels (secondary and academic) and among men. Television, newspapers, websites and social networks have shown themselves to be sources that have brought most of the good knowledge, compared to the friends and family members. These observations make it possible to know both the groups of people requiring additional awareness and the tools to be used to improve their level of knowledge. The proportion of people who reported knowing COVID-19 in this study is comparable to that observed in RD Congo, among ISTM students in Lubumbashi (91.6\%) [6], the workers in the private pharmacies in Kinshasa (100\%) [4], as well as the general population in Mbujimayi city (97.0\%) [19], and Gbado-Lie city (91.5\%) [18]. Such a level of knowledge of COVID19 among population, has also been reported in other countries as well $[7,8,14,16]$, and it can be explained with the popularity that this disease has gained by the speed of its spread and its socioeconomic impact across several countries [63]. This popularity can also be explained by the extent of awareness around this disease [4]. The significant predominance of academics among those claiming knowledge of COVID-19 has also been reported by other authors [4, $8,13,14]$ and can be explained by their ability to tap into various information sources. This gap in knowledge levels of the COVID-19, observed between study levels also leads to suspect a very low level of knowledge of this disease, among people who have not studied.

Sources of knowledge about the COVID-19 are predominantly the media (television, and radio) and social networks. The predominance of the media among the sources of information on the aforementioned disease was also observed in DR Congo among ISTM students in Lubumbashi [6] and workers in private pharmacies in Kinshasa [4]. These observations show the importance of the media's contribution to informing the population about the COVID-19 in DR Congo. These results also assume that the population living in the outskirts of the city (large part of the Annexe Commune, Figure 1), not supplied by electric current, could be underinformed or badly informed about the COVID-19. The predominance of people who know the COVID-19 as a viral infection is another element showing the level of good knowledge of this disease by the surveyed population. However, such knowledge can significantly contribute to improving prevention practices in the population only if they also have additional information such as the size of the virus, its duration under different conditions, etc. [64]. Most of informant know that COVID-19 is transmitted by respiratory droplets, which is correct knowledge [8]. The predominance of this response in the surveyed population is an asset for the emergence of good practices such as distancing between individuals, especially with those who cough, and covering the mouth to cough [64]. The incubation period of COVID-19 was correctly declared by the majority of 
surveyed people. Indeed, this good knowledge is an asset that can allow the population to identify their contacts in the event of confirmed contamination. On the other hand, good knowledge of the incubation period can help the population to take adequate precautions and observations, in the presence of a person freshly coming from an area with high risk of COVID-19 contamination [65].

The correct knowledge of the COVID-19 symptoms (headache fever and cough), observed in $69.0 \%$ of the surveyed people (Table 2), shows that most of them can help to identify people with suspicion of this disease, and can facilitate the detection of positive cases in their entourage [7]. This reflection can also be valid for the correct knowledge of the organ system (respiratory system) affected by COVID-19, reported by $78.0 \%$ of all informant (Table 2). However, the fact that the population knows the symptoms attributed to this disease and the organs affected, is among the parameters facilitating self-medication against COVID-19; as is the case with most of the surveyed people (Table 4). However, Baj et al. [66], reported that symptoms related to this disease can also appear in several other pathologies. They therefore recommends that the precise diagnosis be established in all cases where COVID-19 is suspected, before establishing treatment [66]. This situation shows that it is important to educate the population to use the symptoms associated with COVID-19, to contact the empowered services, to establish the precise and acceptable diagnosis. Old and people with other chronic illnesses are known to be most vulnerable to COVID-19 [16]. This knowledge was observed in most of the surveyed people (Table 2). Such knowledge is an asset that can allow the population to take necessary precautions and strict measures for their protection and that of sensitive people, living in their encouragement [64]. Despite their information sources, several interviewed people said they were sufficiently informed about COVID-19, while a significant fraction also admitted to being underinformed about this disease. This would be due to the fact that some people would not have access to continuous information on COVID-19, even though this is a very rapidly evolving pandemic $[8,15]$. Since those who said they were underinformed are predominantly women and those with primary education; awareness raising targeting these groups is essential.

In relation to attitudes of surveyed people (Table 3), most admitted to being frightened by the human-to-human transmission of the COVID-19. This attitude has also been reported among the population of northern DR Congo, in Gbado-Lite city [18]. This is a negative attitude that would be linked to the panic created by the level of health and socioeconomic disruption caused by this disease $[67,68]$. According to Peng et al. [8], negative attitudes have a negative influence on the psychological level, and can lead to a certain regression in the practice of preventive measures. For this, these authors recommend taking a psychological approach to the population at improving attitudes and promoting collective prevention measures. There is an inverse correlation between COVID-19 knowing and being afraid. This situation would be due to the fact that the luck of COVID-19 knowledge, would lead to the ignorance of its pathological consequences and therefore, a certain psychological insensitivity to this disease. In addition, other positive attitudes were observed among the most of informant who hope that COVID-19 pandemic can end, and feel they are able to withstand the COVID-19 pandemic emergence. The belief in the pandemic end, would be due to the confidence placed in the efforts made by the government of DR Congo in the fight against this disease and the regular reports of people who recover from this disease in our country [5].

The predominance of people who have reported being impacted by the COVID-19 pandemic in their lives, can be explained by negative facts such as the economic crisis and the suspension or closing of several activities due to the spread of this disease [63]. Moreover, the closure of schools and universities was cited by the most as being their major obstacles during the COVID-19 pandemic. Indeed, at the time of the investigation, universities and schools were closed throughout the DR Congo. Curfews (a restriction on traffic after 9:00 p.m.) and cancellation of mass events are major obstacles in the lives of most people, during the COVID-19 pandemic. By the way, the curfew would have an impact on the people movement and probably on their businesses maintenance, while the cancellation of mass events would have a negative impact on the entertainment of those surveyed. The presence of people who claimed to have no obstacles in regard to the restrictions related to COVID-19, can be explained by the fact that there is a significant fraction of people who declared to exercise any profession at the time of the survey (Table 1).

Table 4 shows that most of surveyed people, practice good protective measures against COVID-19 contamination, namely wearing mask, washing hands and distancing $[8,64]$. This high rate of people practicing the right protective measures is believed to be due to the media awareness about COVID-19, since its inception [64]. Such an impact of the media on the practice of protective measures against COVID-19 contamination has also been reported in other studies $[17,64]$. Significant differences were observed in the gender of the surveyed people and their studies level, with predominance of men and academics. This difference suggests that women and people with primary as well as secondary education would have some negligence in the application of protective measures. These observations also assume that these latter groups would be highly exposed to the COVID-19 contamination. 
The predominance of self-medication among the practices recommended by the surveyed people, in the event of COVID19 symptoms and in the event of direct contact with a person infected with COVID-19, implies that most of these people do not favor screening, in case of symptoms associated with this disease. Thus, there may be in Lubumbashi, several people infected but not identified. According to Pascarella et al. [69], the presence of infected and unidentified people poses a considerable risk for the rapid spread of COVID-19 in a population. This situation shows the need to sensitize the population for screening in order to promote rational and appropriate healthcare. However, high prevalence of selfmedication has been reported by Bashige et al, among students at the University of Lubumbashi (99.0\%), for a several conventional drugs and medicinal plants [70] and in the general population (96.6\%), for antimalarial drugs and medicinal plants used against malaria [71]. In addition, self-medication against the COVID-19 symptoms has also been reported in another study conducted by Sadio et al., in Togo [72]. Literature research has shown that 19/21 medicinal plants cited by the surveyed people, were published as having anti-COVID-19 potential (Table 5). The same is true for conventional drugs, of which 14/17 are used in different management protocols for patients with COVID-19 (Table 6). In addition, the use of medicinal plants to fight COVID-19 has also been reported in the population living in northern DR Congo, in the town of Gbado-Lite [18]. Some medicinal plants such as Zingiber officinale, Artemisia annua, Moringa oleifera, Persea americana, and Gymnanthemum amygdalinum (accepted name of Vernonia amygdalina Delile), reported in the above-mentioned study [18], are also among those cited by the people interviewed in this study. This situation shows that the knowledge allowing surveyed people to practice self-medication would be drawn from the published data and/or shared on websites or social networks, in relation to conventional drugs and medicinal plants with antiCOVID-19 potential. According to Malik et al. [15], the self-medication against COVID-19 has been encouraged by the panic created by reports that so far there is no appropriate treatment for the treatment of COVID-19 disease. These same authors add that self-medication against COVID-19 should be monitored, especially in low-income countries, with inadequate health systems, as it can increase the current health crisis. For Mudenda et al. [73], self-medication during COVID-19 presents risks, particularly in relation to microbial resistance, hypersensitivity reactions to the used products and intoxication. In view of results from this study (Table 4, Table 5, Table 6, Figure 3), sensitization among the Lubumbashi inhabitants is essential to inform them about risks and consequences of self-medication; especially also that several plants are combined among themselves and even with conventional drugs.

Effective of people who have declared themselves ready to rescue healthcare workers in the event of a surplus of people infected with COVID-19, can be explained by the solidarity which is recognized in the African culture [74]. However, such an intention is important for the intervention of the popular mass, but requires that this population be informed more about risks associated with such practice [69]. The fact that most informant can agree to meet people cured of COVID-19, by requiring them some conditions such as wearing a mask and distancing, may be due to the uncertainty about contagiousness of cured persons [75]. Moreover, these conditions can create feelings of frustration and reluctance in people recovered from COVID-19. This situation implies that population must be sufficiently informed about the possibility of transmitting virus after recovery from COVID-19 [76]. The predominance of need to return to daily activities among several interviewees can be explained by the fact that many people have been forced to stop their business because of measures taken by the national authorities. Thus, these people would need to resume their activities to remedy a possible economic crisis [63].

\section{Conclusion}

Most of the inhabitants of Lubumbashi city have good knowledge of COVID-19, whose information sources are predominantly through television and social networks. Several interviewed people admitted to being frightened by the human-to-human transmission of this disease, but hope that it can stop and resume normal life. Wearing a mask, distancing and hands washing are the most cited protective measures; while self-medication with medicinal plants and conventional drugs is the most recommended practice in the event of COVID-19 symptoms or in the event of direct contact with a person infected with this virus. Overall, the KAPs cited by the surveyed people showed significant differences according to gender and study level. Thus, people with a low education, and sometimes also women, have shown significant fractions of people with erroneous knowledge about COVID-19, with negative attitudes and advocating non-recommended practices to protect themselves or fight the symptoms of this disease. Observations from this study show the need to raise awareness among people with low education levels, to improve their knowledge of COVID-19 and the possible consequences of bad practices related to this disease. 


\section{Compliance with ethical standards}

\section{Acknowledgments}

The authors sincerely thank everyone who helped identify the social media groups to which the questionnaire was distributed, as well as anyone who agreed to take the questionnaire online.

\section{Disclosure of conflict of interest}

The authors declare no competing interests.

\section{Authors' contributions}

Henry Manya Mboni and Cedrick Mutombo Shakalenga designed the project and prepared the survey questionnaire, they also collected data together with Arsene Kabamba Tshikongo, Cynthia Kibwe Mwenya, Gaël Nzuzi Mavungu, Osé Moke Mwindu, Jean-Claude Nkwanga, and Trésor Nsumbu Nzuki. Cedrick Mutombo Shakalenga carried out statistical analyzes and prepared the original manuscript. Augustin Mutombo Mulangu, Valentin Bashige Chiribagula, Salvius Bakari Amuri, Joseph Kahumba Byanga and Jean-Baptiste Lumbu Simbi reviewed and corrected the original manuscript. All authors have read and approved the final version of the published manuscript.

\section{Statement of informed consent}

Informed consent was obtained from all individual participants included in the study.

\section{References}

[1] WHO. Coronavirus disease (COVID-19) pandemic. World Heal Organ. 2021.

[2] Hatabu A, Mao X, Zhou Y, Kawashita N, Wen Z, Ueda M, et al. Knowledge, attitudes, and practices toward COVID19 among university students in Japan and associated factors: An online cross-sectional survey. PLoS One. 2020; 15: e0244350.

[3] Kwon S, Lee W, Jin C, Jang I, Jung W-S, Moon S, et al. Could herbal medicine (Soshihotang) be a new treatment option for COVID-19?: a narrative review. Integr Med Res. 2020; 9: 100-480.

[4] Kabamba LN, Kabamba MN, Mukonkole JN, Ngombe SK, Katembo M, Kabyla BI, et al. Connaissances, attitudes et pratiques des travailleurs des officines privées sur le COVID-19: cas de la commune de Kintambo à Kinshasa. 2020; 4: 6-8.

[5] CMR RDC Covid-19. Situation épidémiologique covid-19 en République Démocratique du Congo au 17 Février 2021. Com Multisectoriel La Riposte à La Pandémie Du Covid-19 En RDC. 2021.

[6] Ngoyi JM, Kabamba LN, Tambwe PN, Mutombo JT, Katanga LM, Muganza RB, et al. Connaissances, attitudes et pratiques liées au SRAS-COV-2 (COVID-19) chez les étudiants de l'Institut Supérieur des Techniques Médicales de Lubumbashi. Rev l'Infirmier Congo. 2020; 4: 8-12.

[7] Salman M, Mustafa ZU, Asif N, Zaidi HA, Hussain K, Shehzadi N, et al. Knowledge, attitude and preventive practices related to COVID-19: a cross-sectional study in two Pakistani university populations. Drugs Ther Perspect. 2020; 36: 319-325.

[8] Peng Y, Pei C, Zheng Y, Wang J, Zhang K, Zheng Z, et al. A cross-sectional survey of knowledge, attitude and practice associated with COVID-19 among undergraduate students in China. BMC Public Health. 2020; 20: 12-92.

[9] Wu R, Wang L, Kuo H-CD, Shannar A, Peter R, Chou PJ, et al. An update on current therapeutic drugs treating COVID-19. Curr Pharmacol Reports. 2020; 6: 56-70.

[10] Mputu Kanyinda J-N. Coronavirus (COVID-19): A protocol for prevention and treatment (Covalyse ${ }^{\circledR}$ ). Eur J Med Heal Sci. 2020; 2: 1-4.

[11] Portella SFC, Ghelman R, Abdala CMV, Schveitzer MC. Evidence map on the contributions of traditional, complementary and integrative medicines for health care in times of COVID-19. Integr Med Res. 2020; 9: 100473.

[12] Belete TM. A review on Promising vaccine development progress for COVID-19 disease. Vacunas. 2020; 21: 121128. 
[13] Zhong B, Luo W, Li H, Zhang Q, Liu X, Li W, et al. Knowledge , attitudes , and practices towards COVID-19 among Chinese residents during the rapid rise period of the COVID-19 outbreak : a quick online cross-sectional survey. Int J Biol Sci. 2020; 16: 1745-1752.

[14] Islam S, Emran GI, Rahman E, Banik R, Sikder T, Smith L, et al. Knowledge, attitudes and practices associated with the COVID-19 among slum dwellers resided in Dhaka City: a Bangladeshi interview-based survey. J Public Health (Bangkok). 2020; 1-13.

[15] Malik M, Tahir MJ, Jabbar R, Ahmed A, Hussain R, Ahmed A. Self-medication during Covid - 19 pandemic: challenges and opportunities. Drugs Ther Perspect. 2020; 36: 565-657.

[16] Ferdous MZ, Id SI, Sikder T, Mosaddek SA, Zegarra-Valdivia JA, Gozal D. COVID-19 outbreak in Bangladesh : An online- based cross-sectional study. PLoS One. 2020; 1-17.

[17] Qutob N, Awartani F. Knowledge, attitudes and practices (KAP) towards COVID-19 among Palestinians during the COVID-19 outbreak: A cross-sectional survey. PLoS One. 2021: 16.

[18] Falanga MC, Ndaba MM, Biye TNJ-C, Masengo AC, Basosila N, Iteku BJ, et al. Survey of COVID-19 knowledge by the population of Gbado-Lite city (Nord-Ubangi) in Democratic Republic of the Congo and new research perspectives. Eur J Sci Res. 2020; 158: 157-166.

[19] Mbiya B, Djeugoue S, Kanda E, Mbuyi D, Banza M, Mushiya C, et al. Coronavirus-19 in the Democratic Republic of Congo: public views, attitudes, and beliefs in an unaffected area: the case of the city of Mbujimayi. Eur PMC. 2020: $1-12$.

[20] Mutombo SC, Manya MH, Nsenga NS, Nzuzi MG, Kibwe MC, Maloba MJ, et al. Mineral elements analysis and total flavonoids content in the fresh leaves from two varieties of Hibiscus sabdariffa L. consumed as vegetable in Lubumbashi (DR Congo). World J Adv Res Rev. 2021; 09: 147-155.

[21] Kasongo MP, Mukoko KG, Kipata ML, Lunda IJ-M. Elaboration de la carte géotechnique de la ville de Lubumbashi guide technique de sélection des sites d'implantation d'ouvrages du génie civil. Eur Sci J. 2018; 14: 1857-7881.

[22] Mpinda MT, Abass OK, Bazirake MB, Nsokimieno EMM, Mylor NS, Kayembe KWM, et al. Towards the efficiency of municipal solid waste management in the Democratic Republic of Congo (DRC): Case Study of Lubumbashi. Am J Environ Sci. 2016; 12: 193-205.

[23] Mwembu D. La problématique de l'habitat dans la ville de Lubumbashi (Elisabethville), province du Katanga, 1910-1960. In: Barker-Ciganikova M, Rüther K, Waldburger D, Bodenstein C-P, editors. Polit. Hous. (Post-) Colonial Africa. African Mi, Boston: De Gruyter Oldenbourg. 2020; 121-40.

[24] Nations Unies. Profils de pays 2017: République Démocratique du Congo. Commission Économique Pour l'Afrique Addis-Abeba. 2017.

[25] Macrotrends. Lubumbashi, Republic of Congo Metro area population. 2021.

[26] Wembonyama S, Mpaka L, Tshilolo L. Médecine et santé en République Démocratique du Congo: de l'indépendance à la 3e république. Médecie Trop. 2007; 67: 447-57.

[27] Becker SL, Vogt J, Knopp S, Panning M, Warhurst DC, Polman K, et al. Persistent digestive disorders in the tropics: causative infectious pathogens and reference diagnostic tests. BMC Infect Dis. 2013; 13: 37.

[28] Chenge M, Vennet J, Der V, Porignon D. La carte sanitaire de la ville de Lubumbashi, République Démocratique du Congo Partie I : problématique de la couverture sanitaire en milieu urbain congolais. Glob Health Promot. 2010; 17: 63-74.

[29] Naing NN. Determination of sample size. Malaysian J Med Sci. 2013; 10: 84-6.

[30] CheckMarket. La taille d'échantillon optimale. 2020.

[31] Steyerberg EW, Vergouwe Y, Keizer HJ, Habbema JDF. A comparison of methods for adaptive sample size adjustment. Stat Med. 2001; 20: 3861-73.

[32] Saleh A, Bista K. Examining factors impacting online survey response rates in educational research : Perceptions of graduate students. J Multidiscip Eval. 2017; 13: 63-74.

[33] World Medical Association. World Medical Association Declaration of Helsinki. JAMA. 2013; 310: 2191.

[34] Porras P. Visualization and analysis of biological networks. In: Schneider MV, editor. Silico Syst. Biol. methods Mol. Biol., Singapore: Springer. 2013; 63-88. 
[35] Shannon P, Markiel A, Ozier O, Baliga NS, Wang JT, Ramage D, et al. Cytoscape : A software environment for integrated models of biomolecular interaction networks. Genome Res. 2003; 13: 2498-2504.

[36] Silveira D, Prieto-garcia JM, Boylan F, Estrada O, Fonseca-Bazzo YM, Jamal CM, et al. COVID-19: Is there evidence for the use of herbal medicines as adjuvant symptomatic therapy ? Front Pharmaco. 2020; 11: 581-840.

[37] Haq FU, Roman M, Ahmad K, Rahman SU, Shah SMA, Suleman N, et al. Artemisia annua: Trials are needed for COVID-19. Phyther Res. $2020: 2423-2424$

[38] Yang F, Zhang Y, Tariq A, Jiang X, Ahmed Z, Zhihao Z, et al. Food as medicine: A possible preventive measure against coronavirus disease (COVID-19). Phyther Res. 2020; 34: 3124-36.

[39] Rathinavel T, Palanisamy M, Palanisamy S, Subramanian A, Thangaswamy S. Phytochemical 6-Gingerol - A promising Drug of choice for COVID-19. Int J Adv Sci Eng. 2020; 6: 1482-1489.

[40] Mpiana PT, Ngbolua K, Tshibangu DST, Kilembe JT, Gbolo BZ, Mwanangombo DT, et al. Aloe vera (L.) Burm. F. as a Potential Anti-COVID-19 Plant: A Mini-review of Its Antiviral Activity. European J Med Plants. 2020; 31: 86-93.

[41] Hamza M, Ali A, Khan S, Ahmed S, Attique Z, Ur Rehman S, et al. nCOV-19 peptides mass fingerprinting identification, binding, and blocking of inhibitors flavonoids and anthraquinone of Moringa oleifera and hydroxychloroquine. J Biomol Struct Dyn. 2020; 0:1-11.

[42] da Silva FMA, da Silva KPA, de Oliveira LPM, Costa E V., Koolen HHF, Pinheiro MLB, et al. Flavonoid glycosides and their putative human metabolites as potential inhibitors of the SARS-CoV-2 main protease (Mpro) and RNAdependent RNA polymerase (RdRp). Mem Inst Oswaldo Cruz. 2020; 115: 1-8.

[43] Kanbarkar N, Mishra S. Matrix metalloproteinase inhibitors identified from Camellia sinensis for CoVID-19 prophylaxis: an in silico approach. Adv Tradit Med. 2020.

[44] Hartanti D, Dhiani BA, Charisma SL, Wahyuningrum R. The Potential Roles of Jamu for COVID-19: A Learn from the Traditional Chinese Medicine. Pharm Sci Res. 2020; 7: 12-22.

[45] Ali I, Alharbi OML. COVID-19: Disease, management, treatment, and social impact. Sci Total Environ. 2020; 728 : 138-861.

[46] Panyod S, Ho C-T, Sheen L-Y. Dietary therapy and herbal medicine for COVID-19 prevention: A review and perspective. J Tradit Complement Med. 2020.

[47] Darwin P, Jennifer RO. El consumo de Cinchona officinalis L. durante la emergencia sanitaria COVID-19 en la provincia de Loja, Ecuador. Bosques Latid Cero. 2020; 10: 161-74.

[48] Prieto-Lobato A, Ramos-Martínez R, Vallejo-Calcerrada N, Corbí-Pascual M, Córdoba-Soriano JG. A case series of stent thrombosis during the COVID-19 pandemic. JACC Case Reports. 2020; 2: 1291-6.

[49] Thémans P, Dauby N, Schrooyen L, Lebout F, Delforge M, Nasreddine R, et al. Model informed dosing of hydroxycholoroquine in COVID-19 patients: Learnings from the recent experience, remaining uncertainties and gaps. Br J Clin Pharmacol. 2020: 1-9.

[50] Arshad S, Kilgore P, Chaudhry ZS, Jacobsen G, Wang DD, Huitsing K, et al. Treatment with hydroxychloroquine, azithromycin, and combination in patients hospitalized with COVID-19. Int J Infect Dis. 2020; 97: 396-403.

[51] Miranda-Massari JR, González MJ, Marcial-Vega VA, Soler JD. A Possible Role for Ascorbic Acid in COVID-19. J Restor Med. 2020; 9: 1-7.

[52] Tsala B. Le ministère de la Santé valide Manacovid, la recette congolaise pour vaincre la Covid. Digit Congo. 2021.

[53] Crighton AJ, McCann CT, Todd EJ, Brown AJ. Safe use of paracetamol and high-dose NSAID analgesia in dentistry during the COVID-19 pandemic. Br Dent J. 2020; 229: 15-8.

[54] Wessels I, Rolles B, Rink L. The potential impact of zinc supplementation on COVID-19 pathogenesis. Front Immunol. 2020; 11: 1-11.

[55] Gendrot M, Duflot I, Boxberger M, Delandre 0, Jardot P, Le Bideau M, et al. Antimalarial artemisinin-based combination therapies (ACT) and COVID-19 in Africa: In vitro inhibition of SARS-CoV-2 replication by mefloquine-artesunate. Int J Infect Dis. 2020; 99: 437-40.

[56] Krishna S, Augustin Y, Wang J, Xu C, Staines HM, Platteeuw H, et al. Repurposing Antimalarials to Tackle the COVID-19 Pandemic. Trends Parasitol. 2021; 37: 8-11. 
[57] Lin Y, Wu F, Xie Z, Song X, Zhu Q, Wei J, et al. Clinical study of artesunate in the treatment of coronavirus disease 2019. Chinese Crit Care Med. 2020; 32: 417-420.

[58] Andreakos E, Papadaki M, Serhan CN. Dexamethasone, pro-resolving lipid mediators and resolution of inflammation in COVID-19. Allergy 2020: 1-4.

[59] Negri EM, Piloto BM, Morinaga LK, Jardim CVP, Lamy SAE-D, Ferreira MA, et al. Heparin therapy improving hypoxia in COVID-19 patients - A case series. Front Physiol. 2020; 11.

[60] Vatsalya V, Li F, Frimodig J, Gala KS, Srivastava S, Kong M, et al. Therapeutic prospects for Th-17 cell immune storm syndrome and neurological symptoms in COVID-19: Thiamine efficacy and safety, in-vitro evidence and pharmacokinetic profile. Craig J McClain MedRxiv. 2020: 1-28.

[61] INS. Rapport global: Enquête 1-2-3. République Démocratique Du Congo, Ministère Du Plan et Suivi de La Mise Oeuvre de La Revolution de La Modernité, Kinshasa. 2014.

[62] Subrahmanyam K, Reich SM, Waechter N, Espinoza G. Online and offline social networks: Use of social networking sites by emerging adults. J Appl Dev Psychol. 2008; 29: 420-33.

[63] Ali A, Ahmed M, Hassan N. Socioeconomic impact of COVID-19 pandemic: Evidence from rural mountain community in Pakistan. J Public Aff. 2020.

[64] Puspitasari IM, Yusuf L, Sinuraya RK, Abdulah R, Koyama H. Knowledge, attitude, and practice during the COVID19 pandemic : A review. J Multidiscip Healthc. 2020; 13: 727-33.

[65] Hossain MS, Ferdous S, Siddiqee MH. Mass panic during Covid-19 outbreak- A perspective from Bangladesh as a high-risk country. J Biomed Anal. 2020; 3:1-3.

[66] Baj J, Karakuła-Juchnowicz H, Teresiński G, Buszewicz G, Ciesielka M, Sitarz E, et al. COVID-19: Specific and NonSpecific Clinical Manifestations and Symptoms: The Current State of Knowledge. J Clin Med. 2020; 9: 17-53.

[67] Chen C, Liu L, Zhao N. Fear sentiment, uncertainty, and bitcoin price dynamics : The case of COVID-19. Emerg Mark Financ Trade. 2020; 56: 2298-309.

[68] Nicomedes CJC, Avila RMA. An analysis on the panic during COVID-19 pandemic through an online form. J Affect Disord. 2020; 276: 14-22.

[69] Pascarella G, Strumia A, Piliego C, Bruno F, Del Buono R, Costa F, et al. COVID-19 diagnosis and management: a comprehensive review. J Intern Med. 2020; 288: 192-206.

[70] Bashige CV, Manya MH, Bakari AS, Sangwa KG, Kahumba BJ, Duez P, et al. Prévalence et caractéristiques de l'automédication chez les étudiants de 18 à 35 ans résidant au Campus de la Kasapa de l'Université de Lubumbashi. Pan Afr Med J. 2015; 21: 1-12.

[71] Bashige CV, Bakari AS, Okusa NP, Lumbu SJ-B. Self-medication with antimalarials drugs in Lubumbashi city (DR Congo). GSC Biol Pharm Sci. 2020; 12: 7-20.

[72] Sadio AJ, Gbeasor-komlanvi FA, Konu RY, Bakoubayi AW, Tchankoni MK, Bitty-anderson AM, et al. Assessment of self-medication practices in the context of the COVID-19 outbreak in Togo. BMC Public Health. 2021; 21: 1-9.

[73] Mudenda S, Witika BA, Sadiq MJ, Banda M, Mfune RL, Daka V, et al. Self-medication and its consequences during \& after the Coronavirus Disease 2019 (COVID-19) pandemic : A global health problem. Eur J Environ Public Heal. 2020; 5: 5-9.

[74] Gill L, Kasmir S. Forum: Solidarity. Dialect Anthropol. 2008; 32: 175-175.

[75] Raboisson D, Lhermie G. Living With COVID-19: A Systemic and Multi-Criteria Approach to Enact Evidence-Based Health Policy. Front Public Heal. 2020; 8: 1-7.

[76] Calafiore GC, Novara C, Possieri C. A time-varying SIRD model for the COVID-19 contagion in Italy. Annu Rev Control. 2020; 50: 361-72. 